\title{
BIOLOGICAL CONTROL OF ELM LEAF BEETLE
}

\author{
by Graham S. Thurston
}

\begin{abstract}
The bacterial insecticide Bacillus thuringiensis tenebrionis (Novodor-FC(B) (Btt) protected elm foliage from feeding damage by elm leaf beetle larvae, Xanthogaleruca luteola, when applied to urban elms by mistblower or rotomist. Whereas untreated control trees lost up to $40 \%$ of their total foliage due to elm leaf beetle feeding in a 3 -week sample period, Btt-treated trees suffered only $10 \%$ defoliation. The entomopathogenic nematode Steinernema carpocapsae, when incorporated into tree bands containing cellulose mulch, proved effective at killing high proportions of migrating larvae. The use of the bacterium and nematode together in an integrated program may effectively reduce elm leaf beetle populations, thus eliminating the need for chemical insecticides.

Keywords. Elm leaf beetle; entomopathogenic nematodes; Bacillus thuringiensis; UImus; Xanthogaleruca.
\end{abstract}

The elm leaf beetle (ELB), Xanthogaleruca luteola, is a serious defoliator of elms (Uimus spp.) in North America. This insect was introduced to eastern United States from Europe in the 1830s and has spread across the continent. The beetles overwinter as adults in protected sites, particularly in the attics of older buildings. They emerge from these sites in the spring and commence feeding on newly flushed foliage of nearby elm trees, causing characteristic, often extensive, damage (Figure 1). Adult females lay clusters of bright yellow eggs on the underside of leaves. The larvae hatch after 7 to 10 days and feed by skeletonizing the foliage, leaving the upper cuticle of the leaf intact but destroying all other tissues (Figure 2). In years of severe infestation, defoliation can reach $100 \%$ and result in brown, unsightly trees by midsummer. The larvae feed through 3 instars and after about 21 to 28 days migrate down the trunks of the trees and pupate on or near the ground close to the base of the tree. Once pupation is completed, in approximately 10 days, adults emerge and commence feeding. This second bout of adult feeding can do significant damage to the second flush of leaves on trees heavily defoliated earlier in the year. These adults then disperse to nearby protected sites where they mass to spend the winter. While there can be 3 generations per year in southern areas such as California (Dahlsten et al. 1993), only 1 generation occurs in Fredericton, New Brunswick, Canada, where this study was conducted.

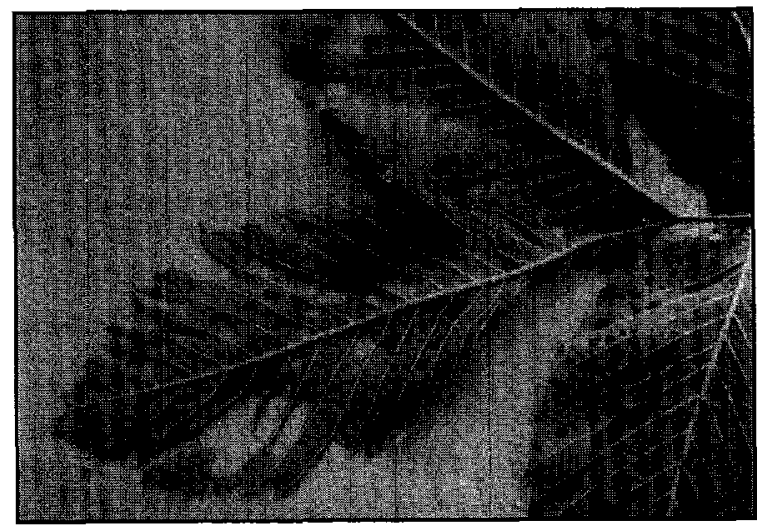

Figure 1. Feeding damage to elm foliage by adult elm leaf beetles. Holes are chewed completely through the leaf tissue, resulting in a "shotgun blast" appearance.

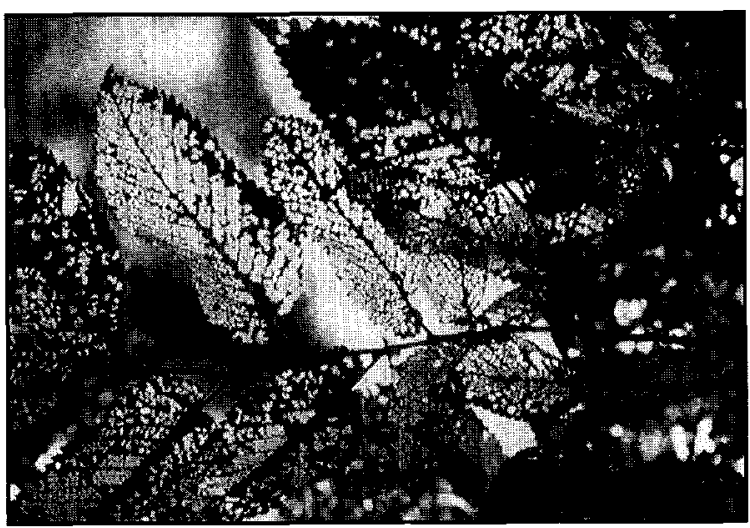

Figure 2. Feeding damage to elm foliage by larval elm leaf beetles. The leaves are skeletonized, leaving the veins and upper epidermis intact. 
Elm trees are important to the character of the city of Fredericton, New Brunswick, which until recently was billed as the "City of Stately Elms." The city, which has an estimated 4,500 elms of varying ages in its downtown core, has successfully dealt with a Dutch elm disease epidemic (Magasi et al. 1993) but a recent, persistent problem with elm leaf beetle has resulted in a rapidly increasing rate of tree mortality (Fredericton Tree Comm.1995,1996). Although several chemical insecticides are registered for use against elm leaf beetle in Canada, the use of these agents in urban areas is limited due to public health and environmental concerns. Therefore, Natural Resources Canada-Canadian Forest Service, in collaboration with the city of Fredericton, initiated an investigation into possible alternatives to chemical control of larval elm leaf beetle.

Two biological control agents were tested: Bacillus thuringiensis tenebrionis (Btt) and entomopathogenic (insect-killing) nematodes. Btt is a bacterial pathogen of insects and must be ingested to be effective. This particular subspecies of $B$. thuringiensis is active only against beetles and, at the time this study was done, was registered in Canada for Colorado potato beetle control. The research conducted for this study was in support of a label expansion to include elm leaf beetle; the product used (Novodor-FC®) is now fully registered for use against elm leaf beetle larvae in Canada. Entomopathogenic nematodes in the genus Steinernema are naturally occurring, soil-dwelling pathogens of insects. While their natural environment is the soil, they can be used in other situations; in this study, they were incorporated into cellulose mulch tree bands to target the larvae as they migrated down the tree to find pupation sites. These organisms are currently exempt from all registration requirements in Canada and the United States.

\section{Materials and Methods}

Bacterium spray trials. Bacillus thuringiensis tenebrionis was supplied by NovoNordisk (now owned by Abbott Laboratories, Ltd.) as NovodorFC@. This product contained 15,000 infective units per gram and was diluted $1 / 12$ (1994) or $1 / 10$ and $1 / 20$ (1995) with water immediately before ap- plication. Application dates were July 13 in 1994 and July 14 and 15 in 1995 . Trees used in this study were American elm (UImus americana) from 4 to $20 \mathrm{~m}$ (13 to $66 \mathrm{ft}$ ) in height. Treatments were applied to trees in the Dutch elm disease management area in downtown Fredericton starting at dawn on the given days and continuing until wind speeds had increased sufficiently to prevent spraying (due to research permit restrictions). Applications were originally scheduled for a few days after initial egg hatch. However, treatments were late because of permit acquisition delays (1994) and equipment problems (1995). Treatments were therefore made after peak egg hatch, which is quite prolonged, and considerable larval feeding had already occurred by that time.

The bacterium was applied by hydraulic sprayer and boom truck to larger trees and by backpack mistblower and hydraulic sprayer to smaller trees in 1994. In 1995, the hydraulic sprayer was replaced with a truck-mounted roto-mist. Selected trees were sprayed until good coverage was achieved. Fifteen trees per treatment were used in 1994, and more than 20 were used in 1995.

Sampling for treatment efficacy consisted of assessing the degree of defoliation on treatment and control trees using a visual standard (Dahlsten et al. 1993). Assessments were made on two 45-cm (18-in.) branch tips per tree, selected at random. Defoliation of each branch tip was determined independently by 3 people and the rating given the tree was an average of the 6 responses. This assessment was done immediately before treatment dates and again 2 or 3 weeks later. Foliage protection was determined based on the change in the defoliation percentage of treated trees compared to the change in defoliation percentage of untreated trees over that time period.

Nematode trials. The insect-pathogenic nematode Steinernema carpocapsae was reared in the larvae of greater wax moth (Galleria mellonella) for use in this study. This species of nematode has been found to be pathogenic to ELB in lab and field trials (Kaya et al. 1984; Eidt 1994). The nematodes have been shown to be ineffective when used in foliar spray trials against larval ELB (Kaya et al. 1981). Trunk banding with 
nematodes incorporated into the band material has been used for other tree pests with varied results (Kaya et al. 1984; Reardon et al. 1986). However, this technique has not previously produced good results with ELB (Eidt 1994), possibly due to materials used in the bands. For the present study, band material was selected based on nematode persistence and infectivity trials using a variety of materials (data not presented). The material selected was a cellulose mulch (hydromulch). Nematodes were added to the mulch at the rate of 200,000 in $200 \mathrm{~mL}$ water per $L$ (6.6 oz per gal) of mulch. The nematode-treated mulch was placed into tree bands constructed of polyethylene film lined with burlap, open at the top and firmly affixed at the bottom to the trunk of the tree. Bands were $45 \mathrm{~cm}$ (18 in.) high and encircled the tree. Bands were placed approximately 2 to $3 \mathrm{~m}$ (6.6 to $9.8 \mathrm{ft}$ ) from the ground at the very beginning of the period when the elm leaf beetle larvae migrate to pupation sites. A minimum of 5 and a maximum of 10 trees per treatment were banded each of the 2 years. Efficacy was determined by removing subsamples of the mulch containing insects from each band 2 to 3 weeks after they were set up, removing all insects from this material, and determining percentage of larvae dead and cause of mortality.

\section{Results and Discussion}

Bacterium spray trials. Novodor-FC® reduced feeding damage by larval ELB when applied by hydraulic sprayer or as a mist (Figure 3 ). There was a reduction in the total defoliation of treated as compared to untreated trees, and dead ELB larvae were observed several days after $B t t$ application only in treated trees. The hydraulic sprayer resulted in considerable product wastage; after spraying was completed, the ground under sprayed trees was noticeably very wet. Moreover, spotty coverage was a problem on the larger trees. This was particularly noticeable on several trees that had good coverage in some areas of the crown (and hence good foliage protection in those areas) but poor coverage in other areas of the crown-resulting in patchy, intense defoliation. During 1995, when a roto-mist was used, uniform coverage of target trees was achieved with less mate- rial (4.5 L [1.2 gal] per tree versus $20 \mathrm{~L}$ [5.3 gal] per tree in 1994) and no loss in foliage protection. Coverage on the smaller trees, using either type of spray equipment, was much more uniform, due to the greater ease of reaching the target.

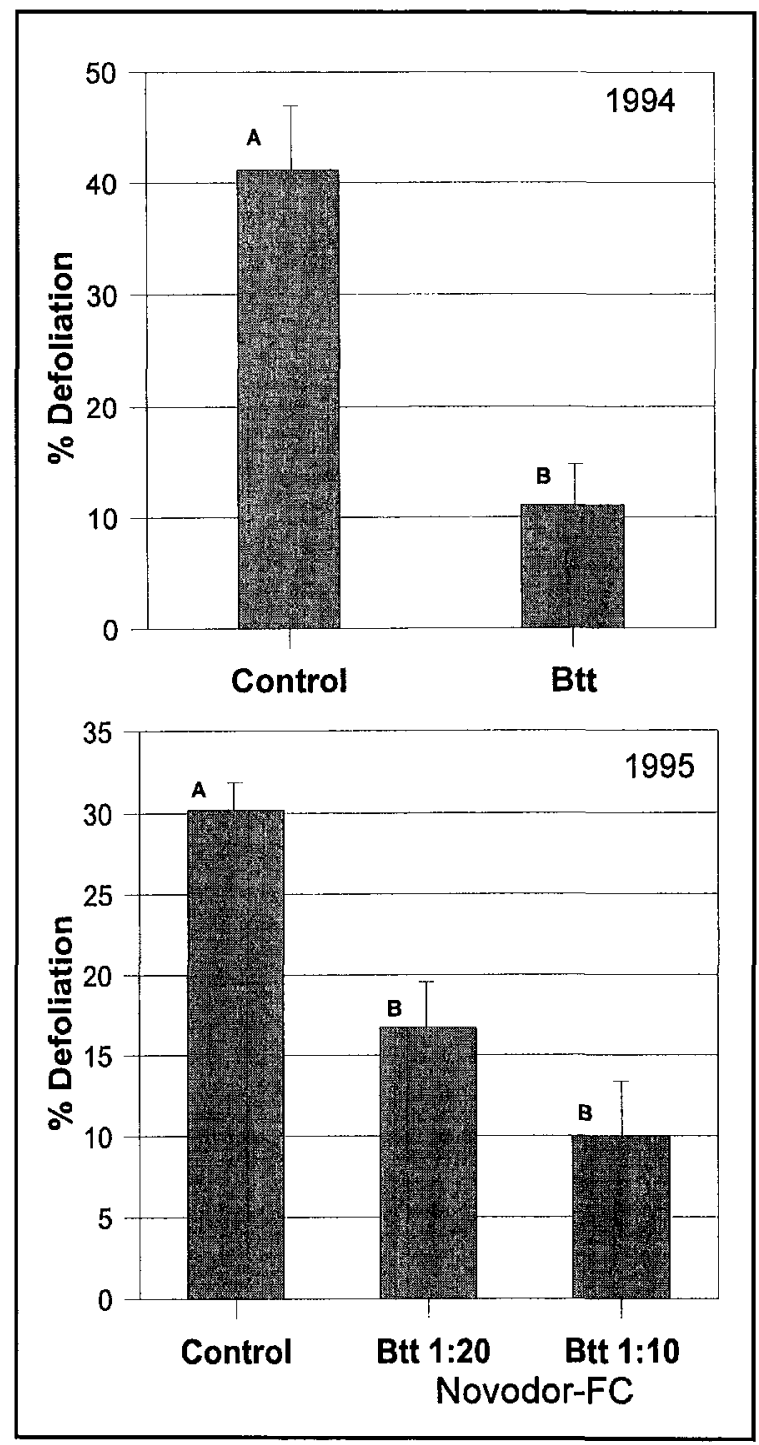

Figure 3. Percentage of defoliation for untreated elm trees and trees treated with the Novodor-FC@ formulation of Bacillus thuringiensis tenebrionis. The percentage of defoliation shown is that occurring between the 2 sample dates only ( 3 weeks in 1994, 2 weeks in 1995). Means with the same letter are not significantly different, Tukey's studentized range test, $\boldsymbol{P}=\mathbf{0 . 0 5}$. Error bar is + s.e. 
Each of the dilution rates used for Novodor$\mathrm{FC} B$ in this study resulted in significantly less defoliation on the treated trees than on the untreated controls (Figure 3). This contrasts with findings by Dahisten and coworkers (Dahisten et al. 1993, 1994), who found that Btt was ineffective. On the other hand, Cranshaw et al. (1989) and Wells et al. (1994) determined that Btt can provide good ELB control in a field setting. The discrepancies between the various studies could be due to differences in timing of application, temperature and weather conditions postapplication, product viability, and formulation, all of which can affect field efficacy.

Greater foliage protection may have been achieved in the present study had it been possible to apply the treatments according to the original schedule. However, because Btt has a residual activity of only a few days in the field (Cranshaw et al. 1989) and because ELB has a prolonged egg hatch period (at least 4 weeks in New Brunswick), 2 applications at 2 weeks apart may be necessary to protect the foliage. In this study, even though significant reduction in defoliation was obtained in the sample period, treated trees were almost as badly defoliated by the end of the summer due to feeding damage by larvae that eclosed after the Btt residual period and because significant amounts of defoliation had occurred before treatment (mean pretreatment defoliation ranged from $19 \%$ to $40 \%$ ). A repeat application may be especially important in localities that have more than 1 ELB generation per year. In some situations, the need for repeat application will make the use of Btt cost prohibitive. However, because of the aesthetic value of specific trees, because the options for control of this insect may be severely limited in some jurisdictions, and because of the expense of removing trees that have succumbed to the stress of repeated defoliation, Btt may be a viable option, notwithstanding its relatively high cost.

Nematode trials. The nematode $S$. carpocapsae effectively killed a large proportion of the larvae migrating down the trunks of trees to locate pupation sites (Figure 4). Larval mortality in tree bands lacking nematodes was also high, probably due to the mulch providing a suitable

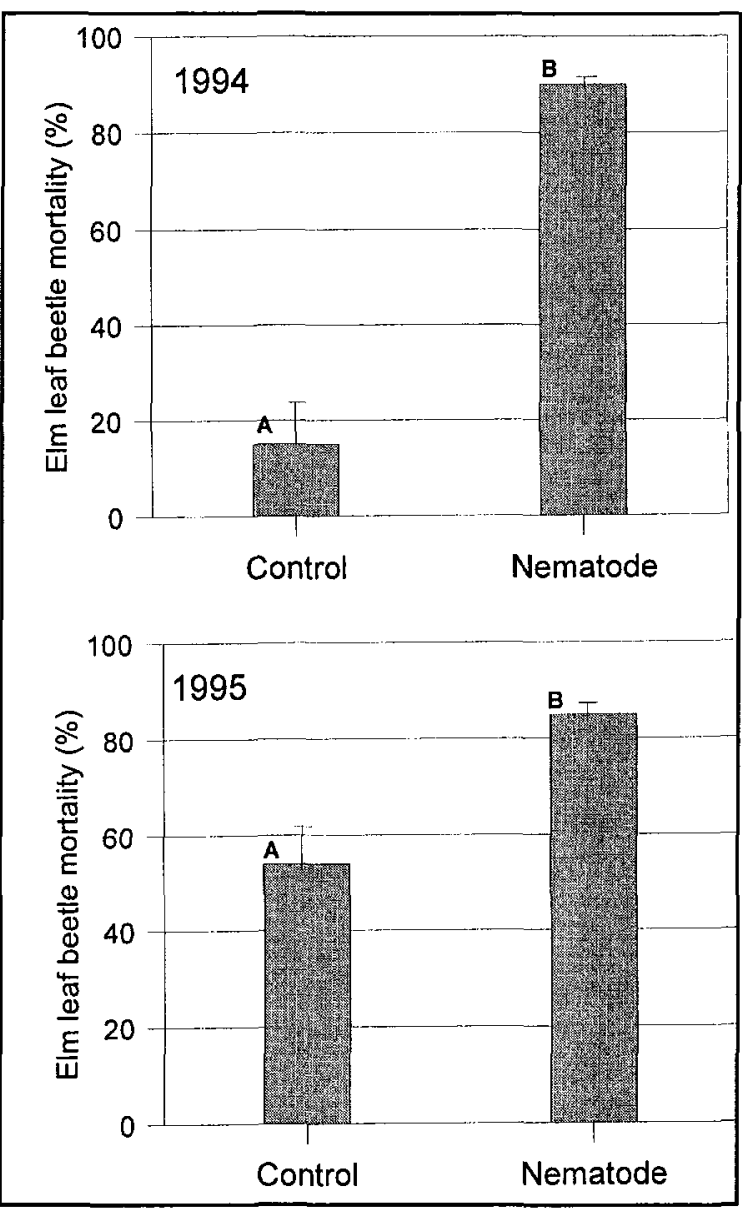

Figure 4. Mortality of elm leaf beetles from cellulose-mulch-filled tree bands treated or untreated with the entomopathogenic nematode Steinernema carpocapsae. Means with the same letter are not significantly different, Tukey's studentized range test, $\boldsymbol{P}=\mathbf{0 . 0 5}$. Error bar is + s.e.

place for predators, as well as the moisture encouraging the action of pathogens. Several predators were observed active in the bands (e.g., earwigs, ants, carabid beetles), and the insectpathogenic fungus Beauveria bassiana was isolated from ELB cadavers taken from both treated and control bands. Control mortality was much lower in 1994 than in 1995, probably because the 1994 site involved isolated trees in a mowed grass field, whereas the trees in the 1995 study were all located in homeowners' backyards. The backyard sites consisted of much more diverse habitats and may have contained a greater diversity 
of potential predators than the site in the relatively uniform field.

The nematodes reproduced in ELB in the tree bands in both years, and the nematode population persisted and was infective until the bands were removed, approximately 1 month after they were established. Nematodes were observed in ELB cadavers recovered from the treated bands but never from cadavers in the control bands.

The efficacy of nematodes in bands in this study is much greater than that found in studies on other insect species (Kaya et al. 1981, 1984), possibly because of the construction of the band material. In other studies, bands were constructed of thin layers of materials such as felt or burlap. In this study, care was taken to select a band that would allow long-term survival of the nematodes, would retain moisture well, and was readily available and cheap. Cellulose mulch fits these criteria well.

Even though larval mortality was quite high in the treated bands, it is unlikely that this technique alone would reduce ELB populations in an area sufficiently to prevent defoliation the following year. This is because, although most larvae migrate down the trunk to locate pupation sites, a significant proportion of them drop directly to the ground, bypassing the bands. In addition, some pupate in crevices on the tree trunks above the level of the bands. Thus, the tree-banding technique may serve to reduce populations on a very local level only and may be unlikely to provide good results as an areawide control measure.

\section{Conclusion}

With the increasing demand for alternatives to broad-spectrum chemical control agents for insect pests, particularly in urban environments, research into possible integrated pest management options is increasing. The use of natural pathogens such as bacteria and nematodes for insect control is becoming more attractive. Bacillus thuringiensis tenebrionis has been shown to be effective against the elm leaf beetle and is likely to play an important role in managing this insect's populations.
Entomopathogenic nematodes dramatically reduce the survival of ELB larvae and pupae when they are exposed to them in tree bands. This tactic alone is unlikely to provide significant area-wide population reductions but it may be useful as a tool for homeowners.

Combining these control strategies into an integrated management program, in conjunction with a campaign to eliminate attractive overwintering sites, could be very important in relieving ELB pressure on urban elms and reducing the mortality rate of susceptible trees.

Acknowledgements. Thanks to Steve Nicholson of Abbott Laboratories, Ltd. for providing the bacterial material used in this study and for discussions on application rates. The city of Fredericton, especially Don Murray, City Forester, generously provided personnel and equipment for the bacterial sprays. Thanks to Charles Weaver for able assistance throughout the study and to B. Pendrel, G. Strunz, and J. Sweeney, who commented on an earlier version of this manuscript.

\section{Literature Cited}

Cranshaw, W.S., S.J. Day, T.J. Gritzmacher, and R.J. Zimmerman. 1989. Field and laboratory evaluations of Bacillus thuringiensis strains for control of elm leaf beetle. J. Arboric. 15(2):31-34.

Dahlsten, D.L., S.M. Tait, D.L. Rowney, and B.J. Gingg. 1993. A monitoring system and development of ecologically sound treatments for elm leaf beetle. J. Arboric. 19:181-186.

Dahlsten, D.L., D.L. Rowney, and S.M. Tait. 1994. Development of integrated pest management programs in urban forests: The elm leaf beetle (Xanthogaleruca luteola (Muller)) in California, USA. For. Ecol. Manage. 65:31-44.

Eidt, C.C. 1994. Personal communication. Canadian Forest Service, Fredericton, NB. June.

Fredericton Tree Commission. 1995. Unpublished. Report of the Fredericton Tree Commission-1994. $46 \mathrm{pp}$.

Fredericton Tree Commission. 1996. Unpublished. Report of the Fredericton Tree Commission-1995. $45 \mathrm{pp}$.

Kaya, H.K., A.H. Hara, and R.C. Reardon. 1981. Laboratory and field evaluation of Neoaplectana carpocapsae (Rhabditida: Steinernematidae) against the elm leaf beetle (Coleoptera: Chrysomelidae) and the western spruce budworm 
(Lepidoptera: Tortricidae). Can. Entomol. 113: 787-793.

Kaya, H.K., J.L. Joos, L.A. Falcon, and A. Berlowitz. 1984. Suppression of codling moth (Lepidoptera: Olethreutidae) with the entomogenous nematode, Steinernema feltiae (Rhabditida: Steinernematidae). J. Econ. Entomol. 77:1240-1244.

Magasi, L.P., K.J. Harrison, D.A. Urquhart, and D.M. Murray. 1993. Three decades of Dutch elm disease in Fredericton, N.B.: 1961-1990. Canadian Forest Service-Maritimes, Information Report M-X-185E. $39 \mathrm{pp}$.

Reardon, R.C., H.K. Kaya, R.A. Fuscoe, and F.B. Lewis. 1986. Evaluation of Steinernema feltiae and S. bibionis (Rhabditida: Steinernematidae) for suppression of Lymantria dispar (Lepidoptera: Lymantriidae) in Pennsylvania, U.S.A. Agric. Ecosyst. Environ. 15:1-9.

Wells, A.J., R.M. Kwong, and R. Field. 1994. Elm leaf beetle control using the biological insecticide, Novodor (Bacillus thuringiensis subsp. tenebrionis). Plant Prot. Q. 9:52-55.

\section{Graham S. Thurston \\ Natural Resources Canada, Canadian Forest Service - Atlantic Forestry Centre \\ P.O. Box 4000 \\ Fredericton, $N B$ \\ CANADA E3B 5P7}

Résumé. L'insecticide bactériologique Bacillus thuringiensis tenebrionis (Novodor- $\mathrm{FC} \otimes$ ) (Btt) protège le feuillage de l'orme contre les dommages causés par la larve du charançon de l'orme, Xanthogaleruca luteola, lorsqu'il est appliqué sur des ormes avec un vaporisateur. Les arbres traités au Btt ont seulement eu 10\% de leurs feuilles mangées alors que les arbres témoins non traités ont perdu plus de
$40 \%$ de leur masse foliaire par le charançon durant une période d'étude de trois semaines. Le nématode entomopathogénique Steinernema carpocapsae s'est avéré efficace pour tuer de grandes populations de larves migratoires lorsqu'il était incorporé dans des bandes de tronc contenant un paillis de cellulose. L'utilisation de la bactérie en conjonction avec le nématode dans un programme intégré de lutte peut effectivement réduire les populations de charançons de l'orme, éliminant ainsi le besoin d'insecticides chimiques.

Zusammenfassung. Das bakterielle Insektizid Bacillus thurengiensis tenebrionis (Novodor- $\mathrm{FC} \otimes$ ) (Btt) schützt Ulmenlaub vor Blattfraßschäden durch die Larve des Ulmenblattkäfers Xanthogaleruca luteola, wenn es durch einen Nebelsprüher oder Rotorsprüher appliziert wird. Die Btt-behandelten Bäume erlitten nur $10 \%$ Enlaubung, während die unbehandelten Kontrollbäume in einem Kontrolizeitraum von 3 Wochen ca. $40 \%$ ihres Laubes durch die Larvenfraß verloren. Die entomopathogene Nematode Steinernema carpocapsae, die in Baumgruppen mit zellulosehaltigem Mulch eingearbeitet wurde, tötete sehr effektiv hohe Anteile der wandernden Larven. Die Anwendung des Bakteriums und der Nematode zusamman in einem integrierten Programm kann sehr wirksam bei der Reduktion der Käferpopulation sein und dabei die Notwendigkeit zum Einsatz chemischer Insektizide eliminieren.

Resumen. El insecticida bacteriano Bacillus thuringiensis tenebrionis (Novodor-FC@) (Btt) protegió al follaje del olmo del daño por alimentación de la larva del escarabajo, Xanthogaleruca luteola, cuando se aplicó a olmos urbanos con nebulizadores. Los árboles tratados con Btt sufrieron solamente un $10 \%$ de defoliación mientras que los árboles de control no tratados perdieron arriba del $40 \%$ de su follaje total debido a la alimentación del escarabajo de la hoja del olmo en un período de muestra de 3 semanas. El nemátodo entomófago Steinernema carpocapsae, incorporado en líneas de árboles con mulch celulósico, fue efectivo matando altas proporciones de larvas migratorias. El uso de la bacteria y el nemátodo juntos, en un programa integrado, puede reducir efectivamente las poblaciones del escarabajo de la hoja del olmo, eliminado de esta manera la necesidad de insecticidas químicos. 